УДК 338.4

\title{
РЕАЛИЗАЦИЯ СТРАТЕГИЙ ИМПОРТОЗАМЕЩЕНИЯ НА ПРЕДПРИЯТИЯХ ОБОРОННО-ПРОМЫШЛЕННОГО КОМПЛЕКСА
}

\author{
Ларин Сергей Николаевич \\ кандидат технических наук, \\ ведущий научный сотрудник \\ Центральный экономико-математический \\ институт РАН, г. Москва
}

\begin{abstract}
Аннотация: Необходимость минимизации негативного влияния санкционных ограничений на развитие российской экономики сыграла определяющую роль в выявлении и реализации потенциала импортозамещения в ключевых отраслях российской экономики. Актуальность темы статьи определяется местом и значимостью оборонно-промышленного комплекса в составе российской экономики. Основной целью данной работы является выбор в качестве одного из определяющих условий реализации стратегий импортозамещения требования соответствия качества новых видов выпускаемой продукции и замещаемых комплектующих международным стандартам. Предметом настоящего исследования выступает ход реализации стратегий импортозамещения предприятиями оборонно-промышленного комплекса, а объектом исследования стал ряд практических мероприятий в составе. Методологическая основа исследования представлена методами анализа, группировки и сравнения показателей в разрезе отдельных предприятий оборонно-промышленного комплекса. В работе кратко освещены некоторые качественные инфраструктурные сдвиги в реализации стратегий импортозамещения отдельными предприятиями оборонно-промышленного комплекса.
\end{abstract}

Ключевые слова: Российская экономика, санкционные ограничения, оборонно-промышленный комплекс, стратегия импортозамещения.

\section{IMPLEMENTATION OF IMPORT SUBSTITUTION STRATEGIES AT DEFENCE CONTRACTORS}


Abstract: The need to minimize the negative impact of sanctions restrictions on the development of the Russian economy has played a decisive role in identifying and realizing the potential for import substitution in key sectors of the Russian economy. The relevance of the topic of the article is determined by the place and significance of the military-industrial complex in the Russian economy. The main purpose of this work is to select as one of the determining conditions for the implementation of import substitution strategies the requirement of compliance with the quality of new types of manufactured products and replaced components with international standards. The subject of this study is the implementation of import substitution strategies by enterprises of the military-industrial complex, and the object of the study was a number of practical measures in the composition. The methodological basis of the study is presented by methods of analysis, grouping and comparison of indicators in the context of individual enterprises of the militaryindustrial complex. The paper briefly highlights some qualitative infrastructure shifts in the implementation of import substitution strategies by individual enterprises of the military-industrial complex.

Key words: Russian economics, sanction restrictions, defense industrial complex, import substitution strategy.

\section{Introduction}

The purpose of the introduction of sanctions restrictions by Western countries was to contain the development of the Russian economy in every possible way. In order to minimize the negative impact of the sanctions restrictions at the state level, the decision was made to conduct an accelerated diversification of the domestic economy. The complex impact of these circumstances created the necessary prerequisites and favorable conditions for changing the main paradigm of Russia's economic development. The activities of industrial enterprises of the militaryindustrial complex (MIC) are largely related in order to ensure the economic and military security of our country. That is why it was reoriented to the development and implementation of import substitution strategies for the supply of foreign equipment and components by replacing them with similar products of domestic production $[1$, p. $33 ; 2$, p. $21 ; 3$, p. 68].

It is obvious that in modern conditions, the implementation of import substitution strategies is largely a forced measure, which, on the one hand, will support the enterprises of the military-industrial complex in increasing their sustainable development. But, on the other hand, the methods and tools of import 
substitution can significantly limit the development of the Russian economy as a whole, since the lack of foreign-made equipment and components on the market significantly reduces the competitiveness of domestic manufacturers. The result will be the loss of incentives for the production of high-quality products at the level of world standards. Therefore, the successful implementation of import substitution strategies is possible only if the production of high-quality products meets or exceeds world standards [2, p. 22; 4, p.14].

In the article, the implementation of import substitution strategies in the production of certain types of equipment and components within the framework of measures developed in their composition will be shown on the example of individual defense industry enterprises.

\section{Main part}

The import substitution should be understood as a certain economic strategy implemented within the framework of the industrial policy implemented by the state, which is aimed at the development of the production of domestic products. It is carried out by means of replacing equipment and components of foreign production with their analogues produced at domestic industrial enterprises [1, p. 38; 5, p.81]. At the same time, the main goal of implementing the measures of the import substitution strategy is to increase the competitiveness of domestic products and improve their quality indicators through the modernization of production technologies and the introduction of innovations.

The import substitution strategy provides for the replacement of the mass production of products of outdated commodity nomenclature with the increase in the volume of production of scientific and high-tech products. In this juncture it is necessary to increase the level of production development and significantly expand the practice of using innovative technologies [2, p. 25]. These conditions are particularly relevant for our country, since the level of development in certain leading sectors of the Russian economy is significantly lower than the level of production development in the countries that are our economic counterparties.

The basis for sustainable economic development of the Russian economy should be a significant increase in the use of domestic industrial enterprises of domestic resources, as well as the volume of output of their own production. These factors are of paramount importance in the view of the increasing instability of the global economy and further restrictions on the access of Russian enterprises to attract foreign loans. In these circumstances, it is important to understand that the main source of giving the Russian economy a growth impulse should be financial resources 
received in the form of income from the export of domestic products created as part of the implementation of import substitution strategies. For this purpose, the products of domestic production must exceed their foreign counterparts in terms of their quality indicators and be competitive at the world level in order to enjoy high demand in the domestic and foreign markets.

In modern conditions, ensuring the independence of the development of the domestic defense industry from products, equipment and components of foreign production is becoming more urgent than ever. The volume of deliveries of individual products, equipment and components of foreign production for the needs of the Russian defense industry, already in 2013-2015, was estimated at 75 billion rubles. euro [6, p. 131]. Until recently, the annual import of dual-use products and technologies from the EU countries was about 20 billion euro. The use of foreignmade products, equipment and components has helped to reduce the development time of new types of weapons and military equipment, and in some cases, to reduce their cost. Thus, the Armata tank platform, BMP-3 infantry fighting vehicles, Typhoon-K armored vehicles, certain types of warships, a number of samples of the latest aviation equipment and many other systems were equipped with products, equipment and components of foreign production.

In recent years, the industrial enterprises of the Russian defense industry have managed to significantly reduce the dependence of the production of the latest models of the military equipment and weapons on foreign supplies. This was largely due to the successful implementation of import substitution strategies. Today, Russian-made products, equipment and components have been completely replaced by foreign analogues in more than 200 samples of the latest weapons and military equipment (VME), and in another 100 samples of the latest VME products, equipment and components imported from Ukraine have been replaced by domestic analogues.

By mid-2018, the United Shipbuilding Corporation (USC) has fully replaced the gas turbine units (GTU) previously supplied from Ukraine for some types of surface warships with Russian-made products. Moreover, since 2017, USC has started to create and manufacture the latest diesel power plants for other types of surface warships. It is obvious that from 2019, the corporation will be able to produce the entire line of power plants for various types of warships on its own [3, p.68].

The United Engine Corporation (UEC), which is part of the state corporation Rostec, produced 130 VK-2500 helicopter engines in 2018, and in 2019 completed the import substitution program for this equipment in full. The VK-2500 turboshaft 
engine is characterized by the increased reliability and performance, and is controlled by a modern digital system. The production of this engine made it possible to modernize the line of medium-sized combat helicopters of the Mi and Ka families. Compared to the basic TV3-117VMA engine, the VK-2500 engine has a higher power by $15-20 \%$, is equipped with a new digital automatic control and control system, and has an increased operational life [7].

The United Instrument Corporation (UIC) is a leading supplier of communication automation tools and systems, as well as telecommunications equipment for the Russian defense industry. The world leaders in the development of the latest information products and management systems comprise such well-known manufacturers as SAP, Oracle, IBM, Microsoft, as well as a number of other American, European and Asian companies. However, such a situation cannot be considered acceptable for the control systems of the Russian defense industry produced by enterprises of the Russian defense industry. It seems obvious that today all information in the Russian defense industry (regulatory, financial, design, production, military, etc.) must be reliably protected and inaccessible to any external threats. The equipment and software used must guarantee the complete impossibility of external interference, exclude any possibility of unauthorized removal or copying of information, and maintain stable performance under any circumstances [8, p. 119].

In recent years, UIC has made significant progress in solving the issues of "technical vision", DBMS, and artificial intelligence. In particular, the technology of computer analysis and processing of large volumes of text information of different levels of complexity has been developed. The uniqueness of this technology is achieved through the use of advanced capabilities of Big Data analysis systems, information processing using multi-format databases, and system organization of document flow. Such technologies can now create world-class companies, like Google or Facebook. For UIC, the creation of such a technology was the implementation of one of the measures of the import substitution strategy [9]. It should be noted that this technology is completely Russian, created without any assimilation by domestic specialists.

Nowadays, one of the priority developments of the UIC is the creation of a unified modular software platform for design and production. Its implementation has opened up new opportunities for the Russian defense industry enterprises in the field of conducting a complete cycle of design and technological preparation of any production: from designing of a three-dimensional model of the product to conducting the necessary calculations and developing design documentation for the 
serial production of finished samples. This product is developed on the basis of the software only produced in Russia, which can be used without restrictions at the enterprises of the Russian defense industry.

\section{Opinions}

In the course of research were obtained certain results, which served as basis for following opinions.

1. It was substantiated that the successful implementation of the import substitution strategy will contribute to the stable growth, as well as to the following development of the Russian economics. It will be a pacing item for the increasing of the competitive ability of the national production at the world level and for its dominance over foreign analogues as to its qualitative indicators.

2. It has been established that nowadays the level of several branches of Russian economics remains rather high. In order to decrease the import dependency level was developed a complex of measures within import substitution strategies, as well as were established terms for the material curtail of the share of the import equipment and completing parts in conformity with the basic nomenclature of the manufactured production.

3. Industrial enterprises of the Russian MIC managed to decrease considerably the dependence of the manufacturing of cutting-edge AME samples from military supplies. The example of several Russian MIC enterprises shows prospects of the successful implementation of adopted import substitution programs and strategies.

\section{References}

1. Gousev M.S. Import Substitution as Economic Development Strategy // Forecasting Problems. - 2016. - №2. - P.30-43.

2. Kleiner G.B. Import Substitution as the Mirror of the Modern Russian Economics // Economic Renaissance of Russia. - 2016. - №3(49). - P.19-26.

3. Soloviev A.I. Import Substitution in Russia: Problems and Ways of Solving // Economics. Taxes. Law. - 2016. - №4. - P.66-71.

4. Heifets B.A. Import Substitution and Competitive Ability // Russia and Modern World. - 2016. - №2. - P.6-21.

5. Doubrovina T.A. Import Substitution in the Machine Building Industry // Belgorod Economic Herald. - 2016. - №2(82). - P.78-82. 
6. Borisova D.O. Import Substitution of the Military Production as the Principle of Activities of Subjects of the Military \& Technical Cooperation // Law and State: Theory and Practice. - 2016. - №1. - P.130-133.

7. Condition and Prospects of the Import Substitution in the MIC of Russia [Electronic resource]. URL - http:// www.arms-expo.ru/news/modernizatsiya_i_ importozameshchenie/sostoyanie_i_perspektivy_importozameshcheniya_v_opk_ rossii/ (date of address: 13.06.2021).

8. Faltzman V.K. Import Substitution in FES and MIC // Economic Issues. 2015. - №1. - P.116-124.

9. Import Substitution - the Priority Task of the Defense Industry [Electronic resource]. URL - http://rostec.ru/news/4516660/ (date of address: 13.06.2021). 